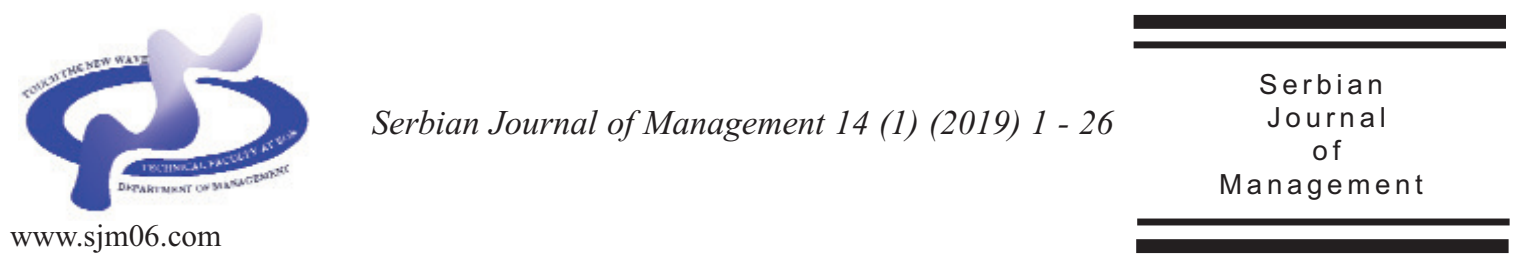

\title{
DOES SEARCH ENGINE QUERY DATA CONTRIBUTE TO RETURNS AND LIQUIDITY?
}

\author{
Ridwan Nurazi and Berto Usman* \\ University of Bengkulu, Faculty of Economics and Business, Department of Management, \\ Jln. WR. Supratman, Kandang Limun, 38371 A - Indonesia \\ (Received 12 September 2017; accepted 02 April 2019)
}

\begin{abstract}
This study attempts to identify the impact of investor's attention which is surrogated by the search engine query data on the internet using Google on returns and liquidity. The data used in this study is extracted from Google Trend data set, and hand-collected data from the Indonesia Capital Market Directory (ICMD). By employing panel data analysis, our results show that search engine query data (information retrieval) by using the internet (Google) is clearly an important method of attenuating the level of asymmetry information between the informed and un-informed investors. Moreover, the utilization of microeconomic factors such as financial or non-financial information that can be easily obtained from the annual reports are strongly useful in helping investors preparing their portfolio of investment. Meanwhile, the macroeconomics factors such as inflation, interest rate, exchange rate, and GDP are the country-level effect which results in either positive or negative impact on returns and liquidity. By employing 83 samples and six years time period of observation, we infer that information retrieval through the search engine query data on the internet, macroeconomics factors and microeconomics factors are strongly and significantly related to returns and liquidity in the Indonesia stock exchange.
\end{abstract}

Keywords: Internet, Google, microeconomics, macroeconomics information

\section{INTRODUCTION}

Deloitte Access Economics Report (2011), which is released by Deloitte as a Google representative of the Asia Pacific region, reveals that internet has changed the way of population in utilizing technology, particularly pertaining to information retrieval on the internet. Though that in the past time, the procedure of information retrieval could not be done as easy as the present days. Before internet 2.0 was booming, the information disclosure and information search activity were manually

\footnotetext{
*Corresponding author: berto_usman@unib.ac.id
}

DOI: $10.5937 /$ sjm14-14992 
conducted (e.g., firms did information disclosure either voluntarily or mandatorily through the annual reports, which were sent to investors and or multi-stakeholders in the form of firms' prospectus). However, nowadays the process of searching information has shifted from the manual to the digital method (Ashbaugh et al., 1999; Zhang et al., 2013; Usman \& Tandelilin, 2014). For instance, the use of search engine, two-way communication via email, social media platforms (twitter, facebook, etc) and or World Wide $\mathrm{Web}^{1}$, regarding the activities of information disclosure, and information retrieval on the internet have implications to the ease of economic transactions. This procedure can be applied without boundaries in terms of space and time limit (Aerts et al., 2008; Dergiades et al., 2015).

The high intensity of internet utilization can be attributed to the economic development, especially in the capital market sector. Seminal studies have examined the phenomenon of Internet usage to measure the stock market performance in developed countries. For example, Bank et al., (2011) examine the information retrieval via the internet on the stock performance for companies incorporated in the German Stock Exchange (Xetra). They employ Internet Search Volume index (ISV) in counting the specific inquiries about the related sample in Germany. Further, Da et al., (2011) also conduct quite similar study by testing the stock performance in American Stock Exchange (NYSE) as their object. The recent study of Dergiades et al., (2015) reports that information contained in social media and web search intensity (Google) influence the financial market in five different European stock markets (Greek, Ireland, Italy, Portugal, and Spain) as well as the two main stock markets in France and Netherlands.
Following the motives of previous researchers in the developed countries, we conjecture that internet also plays an important role, particularly as information provider that can be accessed easily, fast, and open access to multi-stakeholders.

Since the phenomenon of internet has been growing and further penetrating the area of economic, accounting, and finance, it is highly considered by many researchers that internet is useful in boosting and fostering the capital market sector (Bank et al., 2011; Da et al., 2011; Drake et al., 2012; Usman \& Tandelilin, 2014; Nurazi et al., 2015a). Given that, internet is considerably utilized by market participants in many ways. On one side, internet is commonly used by the company to disclose information. On the other side, information disseminated by the companies is necessarily important for the investors and prospective investors (Joseph et al., 2011; Zhang et al., 2013). Prior study reports that among the market participants, there are two types of investor regarding their level of knowledge. Copeland, (1976) argues that investors are divided into two forms ${ }^{2}$. First, sophisticated investors who are better informed about the firm condition (also known as informed investors), second, investors who have no or less information about the market and the company outlook (known as un-informed investors) and they are more vulnerable compared with the informed investors. The differences between these two types of investors display a very clear condition of asymmetry information among them.

The terminology relating to information asymmetry has emerged as the theory of asymmetry information explains that the achievement of individual will be different from the other competitors. It depends on the number and quality of information as

\footnotetext{
${ }^{1}$ The study of Aerts et al., (2008) points out that the advent of WWW (World Wide Web) is somehow leading the companies to reconsider their reporting and disclosure strategy. It is necessary since they primarily assume that Web offers much more flexibility than traditional reporting which means for both the presentation and content of reporting.

2 In the study of Axjonow et al., (2016) informed investors are also associated with the professional stakeholders (financial analyst, institutional investors, etc) and the un-informed investors are also known as non-professional stakeholders (potential or actual retail investors, consumers, employee, and general public).
} 
obtained by the investors itself (Beretta \& Bozzolan, 2008; Michelon et al., 2015). More specifically, this happens since some parties have more advantages concerning the availability of information. The available information is likely enabling them to make better decisions in exploiting the prospective returns and minimizing the potential risks (Joseph et al., 2011; Takeda \& Wakao, 2014; Turan, 2017). In line with these circumstances, there is assumption that this phenomenon not only exists in the developed capital market, but also in the emerging capital market.

Both types of investors as mentioned by Copeland, (1976) have different opportunities in managing their investment achievements. The differences of information they hold are also reflecting the implications of inefficient trading activity in the stock market. By utilizing the internet, we assume that the presence of asymmetry information between the informed and uninformed investors can be reduced. Also, internet considerably provides positive contribution to the public listed companies (PLCs), where the companies and investors could use it as an open source media (Zhang et al., 2013; Turan, 2017). As a result of this, companies no longer need to conventionally publish and disclose information (financial or non-financial ${ }^{3}$ ) through television, newspapers, magazines, catalogs, or printed prospectus to their current or prospective investors. Companies just simply publish the relevant information such as financial statements, firm's prospectus, market outlook with regard to companies' action plan, and rudimentary information which can be identified through public information such as the current stock value, trading volumes, major financial ratios, and recent condition of macroeconomic information (inflation rate, exchange rate, interest rate, and economic growth).

Moreover, besides the internet, the indicators that are commonly used in explaining the variation of capital market performance are the macroeconomic variables. Information about macroeconomic variables can be easily accessed on the internet. Some financial institutions such as the central bank of Indonesia (http://www.bi.go.id/), ministry of finance (https://www.kemenkeu.go.id/), and financial service authority (http://www.ojk.go.id/) have their own virtual media platforms which provide the specific information regarding inflation, interest rates, the exchange rate, economic growth, and other useful financial indicators. Therefore, we aim at investigating the effects of macroeconomic indicators, and microeconomic information which are published as public information on the internet. We specifically use internet and the public information as predictive factors that can explain the variation of market performance for public listed companies (PLCs) in the Indonesia Stock Exchange (IDX).

We consider that the combination of macroeconomic and microeconomic variables as recorded in the activity of search engine query data is based on two underlying theories. The main underlying theory related to the theory of information asymmetry and arbitrage pricing theory (APT) (see. Ross, 1976). In the long discussion of many researchers (Fogler et al., 1981; Peavy \& Goodman, 1985; Sweeney \& Warga, 1986; Kanas, 2008; Verma \& Jackson, 2008; Joseph et al., 2011), the previous theory of Capital Asset Pricing Model (CAPM) mentions that the variation of stock returns can only be explained by one risk factor

\footnotetext{
3 According to the study of Mercer, (2004) in the US setting, manager usually decides to disclose information in numerous venues, including the audited financial statements, meeting with reporters, conference calls with analysts, annual shareholders' meeting and special press release.
} 
known as beta $(\beta)$ (Treynor, 1961). However, as time goes on, the theory is now has been reconsidered. The following new factors emerge such as the Fama three factors, and other possible factors in asset pricing theory. Thus, these theories open an opportunity and allow more than one factors that could be useful as predictors of stock returns variation. Due to the issue of theoretical and empirical gap, we deliberately position our research to extend the number of works of literature in the area of capital market. Therefore, our study is purposed to complement the prior studies by examining the relationship between information retrieval as conducted by the investors and return-liquidity nexus in the Indonesian market.

The rest of the paper is organized as follows. Section literature review provides and elaborates on the works of literature in the leading theories. Further, analysis in the area of investors' attention and its relationship with returns and liquidity is conducted. Section of research method presents the methodological procedures in the data generation, model selction, and the proposed research model. In the section of results and discussion, empirical outputs along with its explanation are written in order to get the comprehensive explanation pertaining to the results of our study. Finally, the section of concluding remarks is the last part where the general overview and conclusions are provided.

\section{LITERATURE REVIEW}

\subsection{Asymmetry Information and Arbitrage Pricing Theory}

Jensen and Meckling, (1976) point out the asymmetry of information as a condition, in which manager has access to the specific information about the company's prospects better than the outsiders. This eventually leads to the emergence of agency theory, which indicates a discrepancy between the degree of information held by managers and information owned by the principal (Nurazi et al., 2015b). However, the asymmetry in this study is not considered as the difference in the level of information between the agent and principal, but more focuses on the difference of information between the informed and un-informed investors (Copeland, 1976).

In line with the concept of investors as expressed by Copeland (1976), investors who participate in the stock market with unequal level of information incline to result in inefficient markets. Informed investors who have the benefits in terms of better and more reliable information will tend to act with the motive to gain better profit than the un-informed investors or other market participants. In this context, the aggrieved party is the un-informed investors. As documented by $\mathrm{Su}$ et al., (2012) the existence of asymmetry information between the two types of investors can be overcomed by searching as much as relevant information on the internet. Da et al., (2011) and Bank et al., (2011) assume that individuals or internet users who search for specific information either by typing the name or ticker symbol of related companies can be indicated as uninformed investors. Drake et al., (2012) further confirm that around the earning announcement date, the level of information retrieval over the internet is significantly different from the normal days. The high searching activity through the internet shows that market participants are attracted to the recent condition of company. They try to find 
as much as available public information on internet. These all actions will eventually contribute to the investors' behavior on the incoming information and the market reaction, since the incoming information will be reflected through the stock price changes.

As the discussion in the works of literature goes further, arbitrage pricing theory (APT) emerged as the continuation of CAPM. APT is considerably able to explain the variations of stock returns in capital market. First, the adherents of CAPM theory assumes that stock returns variation can only be explained by utilizing one risk factor (market risk as measured by beta). However, the debate arises since there is inability to accommodate the provisional estimates of the CAPM. Further, Fama and French, (1995) added risk factors in the form of firm characteristics. Beta $(\beta)$ which was originally to be the sole factor is revised by adding other risk factors such as size, and book-tomarket value $(\mathrm{B} / \mathrm{M})$. Additionally, APT appears as the continuation of three-factor models as revealed by Fama and French, (1995) which can accommodate more than one risk factor in explaining return variation. The other risk factors comprise of macroeconomic variables that are proxied by inflation, interest rates, exchange rate, and economic growth. These variables are the indicators that accelerate the pattern of economic growth. Thus, macroeconomic indicators have allegedly contributed to the development of capital markets and asset pricing.

\subsection{Investors' Attention and Stock Returns}

The concept of investors' attention has been widely studied in the developed capital market such as America, Germany, and the
Netherlands. The attention of investors is one of the factors or variables that is conjectured to influence the volatility of stock returns and the movement pattern of the returns itself. Previous research as conducted by Bank et al., (2011), Da et al., (2011), and Chen, (2011) reveal that the different levels of investors' attention tend to reflect the asymmetry information among them. This inclines to result in the different performances of the investment undertaken by the investors. If this condition goes further, it will lead the un-informed investors to experience inferior performance compared with the informed investors.

When the un-informed investors get the information as the part of firms' information disclosure strategy, the extent of the cost as incurred by the investors in gathering the information will also be taken into account by the firm. Hereby, firms have to be confidence when they evaluate the released information. It is necessary to convince that the disclosed information is meeting the appropriateness. In this respect, Verrecchia, (1990) notes that if the firms release the information by themselves, it is more likely to be less expensive than if the investors collect the information by themselves. This circumstance eventually leads the information to the position where it is available to everyone at low or no cost. Thus, it is prevalently influence the behavior or certain users such as non-informed investors, which has the interest to improve and modify their level of information awareness. As the result of this, the procedure of reassessment on the investors' economics interest emerges (Aerts et al., 2008).

Regarding the usage of information technology as the tool for search query data, prior studies utilize Google as the main indicator in measuring the specific search 
information conducted on the internet. Google is employed to capture the possibility of potential asymmetry information. The researches of Bank et al., (2011), Drake et al., (2012) and other studies report that the higher search engine query data conducted on the internet, results in either positive or negative impact on returns. It denotes that companies are becoming increasingly recognized by the investors. As the consequence, the high level of attention relating to good news tends to make investors selecting the specific stock. While on the other situation, the informed investors may also use the available information to withhold or sell their stocks. In this context, the decision is based on the availability of relevant information which is taken by the investors. Thus, we formulate the hypothesis one as follows:

Hypothesis 1: The higher the attention of investors to the company is associated with the stock returns.

\subsection{Investors' Attention and Liquidity}

In the second hypothesis development, we here argue that investors' attention is supposed to positively influence the liquidity. Consistent with the research conducted by Joseph et al., (2011) and Takeda and Wakao, (2014) the high liquidity indicates propensity of generating higher returns that is triggered by the high level of liquidity. The liquid companies tend to be favored by investors, thus the high demand of increasing stock impacts on the increasing trading volume of the related stock. This, in turn, will also have implications on the increasing returns, where the higher demand toward a limited number of securities will result in a higher stock price. Therefore, the liquidity of some securities will be determined based on the level of investor awareness and their transaction on the related securities. More specifically, as researched by Usman \& Tandelilin, (2014) the prospective investors could simply do a search query on the internet to get as much as relevant information about the company. In the circumstance where investors have a reliable and huge amount of information, they will do more transactions which triggers the volatility of liquidity, particularly based on their ability to use the relevant information in creating the preferable portfolio of investment. Therefore, referring to the aforementioned argument, we formulate hypotheses two as follows:

Hypothesis 2: As the investors are more aware on the incoming information, the stock liquidity will be positively affected.

\section{RESEARCH METHOD}

\subsection{Data Generation}

Our samples were collected from the public listed companies (PLCs) in Indonesia Stock Exchange (IDX) during the period of observation from January 2007 to December 2012. By doing the hand collection data procedure, we screen the annual reports of PLCs which are incorporated in the Indonesian Capital Market Directory report $(\mathrm{ICMD})^{4}$. There are more than 500 PLCs in the IDX. However, we only use companies that considerably get the specific attention from its investors, potential investors, and it should be recorded based on online search query in the Google Trend database. In particular, our sample should have had the high level of information search and

\footnotetext{
${ }^{4}$ Indonesian Capital Market Directory report (ICMD) is the compilation of annual reports from all Public Listed Company (PLCs) in the Indonesia Stock Exchange (IDX). This documentary report loads many specific information about the PLCs characteristics and information regarding the financial statements, companies' profiles, trading activity and so forth.
} 
attracted the investors' attention to explore the related information through the internet. We finally collected 83 companies in monthly time-series data period from January 2007 to December 2012 (The total number of data observation is 89,640 firmmonths obervations).

\section{2 .Variable Definition}

We employ three main variables of interest that are hypothesized in the hypotheses one and two. However, we also use several additional controlling variables that could be obtained from the annual

\section{Table 1. Operationalization of Research Variables}

\begin{tabular}{|c|c|c|c|}
\hline No & Variable & Definition & Measurements \\
\hline 1 & $\begin{array}{l}\text { Investor attention } \\
\text { (GT) }\end{array}$ & $\begin{array}{l}\text { Da et al., (2011) Bank et al., (2011) and Usman \& Tandelilin, (2014), } \\
\text { use the Search Volume Index (SVI) to measure the level of investors' } \\
\text { attention. To quantify the rate information search, we use Google } \\
\text { Trend features as provided by Google. The data of information } \\
\text { search has been scaled and normalized, so that the available data is } \\
\text { ranging from } 0 \text { to } 100 \text { as the highest search. }\end{array}$ & $\begin{array}{l}\text { Continuous data, scaled from } 0 \text { to } \\
\text { 100. The database can be accessed } \\
\text { on https://trends.google.com/trends/ }\end{array}$ \\
\hline 2 & Return (RET) & $\begin{array}{l}\text { Actual return is the return occurs at time t which is counted from the } \\
\text { difference of current stock price and the previous stock price. The } \\
\text { data of stock return used in this study is the monthly returns. }\end{array}$ & $R E T_{i, t}=\frac{P_{i, t}-P_{i, t-1}}{P_{i, t-1}}$ \\
\hline 3 & Liquidity (TV) & $\begin{array}{l}\text { The proxy of liquidity refers to the study of Chordia et al., (2001) } \\
\text { and Chordia et al., (2007). Here, we use Trading Volume which is } \\
\text { calculated by counting the natural logarithm of the number of shares } \\
\text { traded at time t multiplied by the stock price at time t. }\end{array}$ & $T V_{i t y}=\ln \left(V O_{i t y} x P_{i t y}\right)$ \\
\hline 4 & Stock Price $\mathbf{( P )}$ & $\begin{array}{l}\text { We follow the study of Gündüz \& Hatemi, (2005) to use stock price } \\
\text { as the control variables that can affect the variation in liquidity. }\end{array}$ & \\
\hline 5 & $\begin{array}{l}\text { Inflation } \\
\text { (INFLATION) }\end{array}$ & $\begin{array}{l}\text { Inflation is an economic indicator that determines a country's } \\
\text { economic performance in general. }\end{array}$ & Inflation $=\frac{I H K_{n}-I H K_{0}}{I H K_{0}} \times 100$ \\
\hline 6 & $\begin{array}{l}\text { Interest rate } \\
\text { (I_RATE) }\end{array}$ & $\begin{array}{l}\text { The interest rate is a standard reference for the money market and } \\
\text { capital market in determining how well their ability to provide } \\
\text { returns for investors or funders. }\end{array}$ & \\
\hline 7 & $\begin{array}{l}\text { Exchange rate } \\
\text { (E_RATE) }\end{array}$ & $\begin{array}{l}\text { The exchange rates between Indonesian Rupiah (IDR) and US dollar } \\
\text { are the indicator of local currency (IDR) competitiveness on the } \\
\text { major international currency (US Dollar). }\end{array}$ & \\
\hline 8 & $\begin{array}{l}\text { Economic growth } \\
\text { (GDP) }\end{array}$ & $\begin{array}{l}\text { Economic growth is used in projecting the periodic economic } \\
\text { progress. We use the national economic growth as measured by } \\
\text { Gross Domestic Product (GDP). }\end{array}$ & $G D P=\frac{G D P_{t}-G D P_{t-1}}{G D P_{t-1}} \times 100$ \\
\hline 9 & $\begin{array}{l}\text { Trading volume } \\
\text { (LNVOL) }\end{array}$ & $\begin{array}{l}\text { Trading volume is the number of shares traded in the period } \mathrm{t} \text { in a } \\
\text { monthly basis. }\end{array}$ & \\
\hline 10 & $\begin{array}{l}\text { Price Earning } \\
\text { Ratio } \\
\text { (PER) }\end{array}$ & $\begin{array}{l}\text { PER is used to identify the impact of the performance on a certain } \\
\text { firm's stock market that is reflected in its EPS. }\end{array}$ & $P E R=\frac{\text { Market Price }}{E P S}$ \\
\hline 11 & $\begin{array}{l}\text { Age } \\
(\text { AGE) }\end{array}$ & $\begin{array}{l}\text { Age is the time length duration of a company when it firstly begins to } \\
\text { start offering the first stock through the mechanism of Initial Public } \\
\text { Offering (IPO). }\end{array}$ & \\
\hline 12 & $\begin{array}{l}\text { Dividend Payout } \\
\text { ratio } \\
\text { (DP) }\end{array}$ & The percentage of company profits distributed to the shareholders. & $D P=\frac{D P S}{E P S}$ \\
\hline 13 & $\begin{array}{l}\text { Dividend Yield } \\
\text { (DY) }\end{array}$ & The rate of return in the form of dividends. & $D Y=\frac{D P S}{\text { Stock price }}$ \\
\hline 14 & $\begin{array}{l}\text { Deb to Equity } \\
\text { Ratio } \\
\text { (DER) }\end{array}$ & The comparison between corporate debts to total capital. & $D E R=\frac{\text { Total debt }}{\text { Total equity }}$ \\
\hline 15 & $\begin{array}{l}\text { Return on } \\
\text { Investment } \\
\text { (ROI) }\end{array}$ & $\begin{array}{l}\text { The comparison of net profit after tax with investment earnings that } \\
\text { is used to generate profit (Brigham \& Houston, 2007). }\end{array}$ & $R O I=\frac{\text { net profit after tax }}{\text { total assets }}$ \\
\hline 16 & $\begin{array}{l}\text { Return on Equity } \\
\text { (ROE) }\end{array}$ & $\begin{array}{l}\text { The ratio measures the firm's profitability, in which the amount of } \\
\text { the net income is returned to the shareholders in form of the } \\
\text { percentage of shareholders equity. }\end{array}$ & $R O E=\frac{\text { Earning after Tax }}{\text { Total Equity }}$ \\
\hline 17 & $\begin{array}{l}\text { Market } \\
\text { capitalization } \\
\text { (SIZE) }\end{array}$ & $\begin{array}{l}\text { Firm size refers to the market value of company. Hereby, market } \\
\text { capitalization is obtained from the calculation of the stock market } \\
\text { price multiplied by the number of outstanding shares (Chan et al., } \\
2005 \text { ). }\end{array}$ & LnSize $=\operatorname{LnP}_{s} \times \operatorname{Ln} S_{s}$ \\
\hline
\end{tabular}


financial statements of related PLCs through the internet. The controlling variables consist of financial ratios which are considered as the microeconomic indicators. Moreover, the usage of macroeconomic indicators is also considered to investigate the country-level effects on the variation of stock returns and liquidity in the Indonesian capital market. As noted by Mercer, (2004), to empirically measure the quality of incoming information, it can be conducted through two different types of studies. First, it relates to the ${ }^{5}$ archival study and second the experimental study. In the archival study, the form of data used to measure the information focuses on the stock market reaction and the data of analyst forecast revisions. Moreover, the experimental study concerns on the information disclosure as collected from the market participants to rate the information disclosure quality. In this study, the information retrieval uses the archival data in which the available data on the internet is considered as the public information that can be freely accessed by the market participants. The operationalization of variables used in our study can be observed in Table 1.

\subsection{Predictive Panel Regression Model}

We conduct our research by utilizing the combination of cross-sectional and timeseries data (pooled data). Reffering back to the aim of our research, we study the effect of search engine query data over the internet and use the supporting macro and microeconomic indicators in explaining the variation of returns and liquidity. We also employ macro and microeconomics indicators to anticipate the endogeneity problem with regards to the omitted variable bias that may affect the changes in the dependent variables.

In the reference of Gujarati and Porter, (2010) and Baltagi (2008), panel data regression is considered as a good combination when it is viewed from the aspect of data availability. In this case, we use cross-sectional and time-series data to obtain the higher quantity of observation. Baltagi, (2008) shows that there are three approaches that can be employed to perform the testing in panel data analysis. These approaches are pooled least squares models (PLS), fixed effect model (FEM) and the random effect model (REM). Moreover, Baltagi reveals that preliminary studies need to be conducted to find the most recommended model among these three models. In order to get the best-estimated model, we do preliminary test by employing Chow and Hausman test.

The developed model used in this study is divided into two statistical models. We use the first model to statistically test hypothesis one and the effect of each independent variable (variable of interest and control variables) on returns. Meanwhile, the second predictive model is used to test the hypothesis two and to identify the influence of independent variables on liquidity. These two predictive regression models are written as follows.

\section{Predictive Model I}

$$
\begin{aligned}
& R E T_{i, t}=\alpha+\beta_{1} G T_{i, t}+\beta_{2} P R I C E_{i, t}+\beta_{3} L N V O L_{i, t} \\
& +\beta_{4} P E R_{i, t}+\beta_{5} A G E_{i, t}+\beta_{6} D P_{i, t}+\beta_{7} D Y_{i, t} \\
& +\beta_{8} D R_{i, t}+\beta_{9} \text { ROI }_{i, t}+\beta_{10} \text { ROE }_{i, t}+\beta_{11} \text { INFLATION }_{t} \\
& +\beta_{12} I_{-} R A T E_{t}+\beta_{13} E_{-} R A T E_{t}+\beta_{14} G D P_{i, t} \\
& +\sum_{\text {ind }=1}^{24} \beta_{15} \text { Industry }+\sum_{\text {year }=1}^{6} \beta_{16} \text { Year }+\mathcal{E}
\end{aligned}
$$

\footnotetext{
${ }^{5}$ As explained by Mercer, (2004) archival study employs the archival data such as the analyst forecast reports, information that is disclosed by the company through the mechanism of voluntary or mandatory disclosure, and stock prices which reflect the number of information as it regularly changes. Otherwise, the experimental study uses the experimental data which refers to the specific and unique data in the design of several variables manipulation in the experiments.
} 
Predictive Model II

$T V_{i, t}=\alpha+\beta_{1} G T_{i, t}+\beta_{2} P_{R I C E_{i, t}}+\beta_{3} P E R_{i, t}$

$+\beta_{4} A G E_{i . t}+\beta_{5} D P_{i, t}+\beta_{6} D Y_{i, t}+\beta_{7} D E R_{i, t}$

$+\beta_{8}$ ROI $_{i, t}+\beta_{9}$ ROE $_{i, t}+\beta_{10}$ INFLATION $_{t}$

$+\beta_{11} I_{-} R A T E_{t}+\beta_{12} E_{-} R A T E_{t}+\beta_{13} G D P_{i, t}$

$+\sum_{\text {ind }=1}^{24} \beta_{14}$ Industry $+\sum_{\text {year }=1}^{6} \beta_{15}$ Year $+\varepsilon$

The two predictive models are employed in running the statistical procedure. It is clearly seen that both of the models utilize different dependent variables with relatively similar explanatory variables. In the first predictive model, the dependent variable used is RET which is defined as the actual return occurs at time $t$ and is counted from the difference of current and the previous stock price. It is important to note that the type of return used is the monthly returns. Whilst in the second predictive model, we utilize trading volume (TV) as the proxy of liquidity. We follow the study of Chordia et al., (2001) and Chordia et al., (2007) in formulating the trading volume. Hereby, trading volume is calculated by counting the natural logarithm of the number of shares traded at the time t multiplied with the stock price at time $t$.

The other variables as shown in the both predictive models are the independent and control variables. The main independent variable is GT, which is the proxy of investors' attention on the related stocks. GT denotes the search engine query data which has been scaled and normalized by Google feature (Google Trends) as the tool in quantifying the rate of informatin search. Here, the data of GT ranges from 0 to 100 percent as the highest search. Moreover, in testing the effect of investors' attention (GT) on the returns (RET) and liquidity (TV), the support from control variable is needed. These control variables consist of the micro and macroeconomics data such as Inflation (INFLATION), Interest rate (I_RATE), Exchange rate of Indonesian rupiah (IDR) toward US Dollar (E_RATE), Gross Domestic Product (GDP), Stock price (PRICE), Logarithm natural of trading volume (LNVOL), Price earnings ratio (PER), Age (AGE), Dividen payout ratio (DP), Dividen yield (DY), Debt-to-equity ratio (DER), Return on investment (ROI), and Return on equity (ROE).

\subsection{Model Selection}

The determined model will affect the result of statistical output. This indicates that the selection of an appropriate model greatly influences the interaction of every independent variable with the dependent variable in the predictive model. As previously noted by Baltagi, (2008), in the process of estimation with panel data regression model, there are three techniques that can be implemented. To determine which model would be used in each hypothesis testing, chow test is firstly performed. Chow test itself is utilized to compare between PLS and FEM. To compare between FEM and REM, Hausman test is employed (Baltagi, 2008; Gujarati \& Porter, 2010).

Justification with regard to the preliminary study is also carried out in the model selection procedure. Hereby, we considerably require the model which can provide the most efficient estimation output and meet the best, linear, unbiased, and estimator criteria. Testing the combinations of cross-sectional and time-series data in panel data analysis is considerably better than doing the testing by using ordinary least 
square per se (OLS, Gaussian models) (Baltagi, 2008). The obtained results of model selection based on the preliminary study can be seen in Table 2 .

\section{RESULT AND DISCUSSION}

\subsection{Data and Sampling}

The sampling procedure was conducted

Table 2. Chow Test Output for the First Predictive Model on Return (RET)

\begin{tabular}{|c|c|c|c|c|c|c|}
\hline & & & $\begin{array}{l}\text { Indant } \mathrm{Fi} \\
\text { cross-sec }\end{array}$ & $\begin{array}{l}\text { Effects T } \\
\text { n fixed eff }\end{array}$ & & \\
\hline & & RET & & & TV & \\
\hline Effects Test & Statistic & d.f. & Prob. & Statistic & d.f. & Prob. \\
\hline Cross-section F & 0.6285 & $(82,5881)$ & 0.4683 & 1.3462 & $(82,5882)$ & 0.1547 \\
\hline $\begin{array}{l}\text { Note: Chow test is c } \\
\text { vice versa. The techn } \\
\text { generate the statistic } \\
\text { dependent variab } \\
\beta_{7} D Y_{i, t}+\beta_{8} D E R_{i, t} \\
\sum_{i \text { ind }=I}^{24} \beta_{15} \text { Industry } \\
\text { trading volume (TV) } \\
\beta_{1} G T_{i, t}+\beta_{2} \text { PRICE } \\
\beta_{10} \text { INFLATION } \\
\text { IN }\end{array}$ & $\begin{array}{l}\text { cted to decid } \\
\text { of analysis i } \\
\text { ttput of cho } \\
R E T_{i, t}= \\
{ }_{9} R O I_{i, t}+\beta \\
{ }_{\text {Year }=I} \beta_{16} Y e \\
\text { e dependent } \\
\beta_{3} P E R_{i, t}+ \\
I_{-} R A T E_{t}+\end{array}$ & $\begin{array}{l}\text { ether the estil } \\
\text { chow test is t } \\
\text { t on the both } \\
{ }_{1} G T_{i, t}+\beta_{2} I \\
E_{i, t}+\beta_{11} I N \\
\varepsilon \text {. Further, tl } \\
\text { ble is conduct } \\
G E_{i, t}+\beta_{5} D I \\
{ }_{-} R A T E_{t}+\beta\end{array}$ & $\begin{array}{l}\text { on resulted } \\
\text { g the redur } \\
\text { statistical } \\
E_{i, t}+\beta_{3} \\
\text { TION } \\
\text { ccond cho } \\
\text { y impleme } \\
+\beta_{6} D Y_{i, t}\end{array}$ & $\begin{array}{l}\text { I FEM moc } \\
\text { fixed effec } \\
\text { l, where } \mathrm{r} \\
L_{i, t}+\beta_{4} \\
R A T E_{t}+ \\
\text { st using th } \\
\text { the followi } \\
D E R_{i, t}+\end{array}$ & $\begin{array}{l}\text { is better than } \\
\text { Two models w } \\
\text { in (RET) is e } \\
R_{i, t}+\beta_{5} A G E_{t} \\
E_{2} R A T E_{t}+ \\
\text { second predict } \\
\text { model as follo } \\
R O I_{i, t}+\beta_{9} R C \\
+\sum_{Y \text { Year }=I}^{6} \beta_{1:}\end{array}$ & $\begin{array}{l}\text { PLS model and } \\
\text { ere employed to } \\
\text { mployed as the } \\
i, t+\beta_{6} D P_{i, t}+ \\
\beta_{14} G D P_{i, t}+ \\
\text { ive model with } \\
\text { w: } T V_{i, t}=\alpha+ \\
E_{i, t}+ \\
{ }_{5} \text { Year }+\varepsilon .\end{array}$ \\
\hline
\end{tabular}

Table 3. Group of Sample

\begin{tabular}{|c|c|c|c|}
\hline No & Industry Groups & No. of Sample & Percentage \\
\hline 1 & Agriculture, Forestry, and Fishing. & 2 & 2.41 \\
\hline 2 & Animal Feed and Husbandry & 3 & 3.61 \\
\hline 3 & Mining and Mining Services & 8 & 9.64 \\
\hline 4 & Constructions & 3 & 3.61 \\
\hline 5 & Food and Beverages & 8 & 9.64 \\
\hline 6 & Tobacco Manufacturers & 3 & 3.61 \\
\hline 7 & Textile Mill Products & 1 & 1.20 \\
\hline 8 & Apparel and Other Textile Products & 1 & 1.20 \\
\hline 9 & Lumber and Wood Products & 1 & 1.20 \\
\hline 10 & Paper and Allied Products & 5 & 6.02 \\
\hline 11 & Chemical and Allied Products & 1 & 1.20 \\
\hline 12 & Plastics and Glass Products & 2 & 2.41 \\
\hline 13 & Cement & 3 & 3.61 \\
\hline 14 & Fabricated Metal Products & 1 & 1.20 \\
\hline 15 & Electronic and Office Equipment & 1 & 1.20 \\
\hline 16 & Automotive and Allied Products & 8 & 9.64 \\
\hline 17 & Pharmaceuticals & 4 & 4.82 \\
\hline 18 & Consumer Goods & 3 & 3.61 \\
\hline 19 & Transportation Service & 8 & 9.64 \\
\hline 20 & Telecommunication & 4 & 4.82 \\
\hline 21 & Wholesale and Retail Trade & 8 & 9.64 \\
\hline 22 & Hotel and Travel Services & 1 & 1.20 \\
\hline 23 & Holding and Other Investment Companies & 1 & 1.20 \\
\hline \multirow[t]{2}{*}{24} & Others & 3 & 3.61 \\
\hline & Total sample & 83 & 100 \\
\hline
\end{tabular}


on the basis of purposive sampling method. At this stage, we have collected as many as 83 companies from 24 groups of industries. We specifically used 83 cross-sectional data, and monthly time-series observations for 72 months, ranging from January 2007 to December 2012. The sample classification based on the industrial groups can be observed in the Table 3 .

\subsection{Descriptive Statistics}

At this stage, we perform data processing concerning the descriptive statistics output to show the fundamental information related to mean, maximum, minimum value, and standard deviation of each variable. We also classify the sample by dividing them into three category groups of samples based on the sample size. First, we rank the sample from the lowest to the highest market capitalization. As many $30 \%$ companies with the lowest market capitalization are classified as the small-size sample. Companies that are categorized between the small and large market capitalization is determined as the medium-size companies, with the proportion $40 \%$ of the total sample. Finally, the large-size sample comprises of $30 \%$ of companies that have the largest market capitalization. Our sample is scaled based on the company size as suggested by the study of Chan et al., (2005). By partitioning the sample into three groups, we can control the effect of market capitalization in terms of different level search engine query data as conducted by the market participants in Indonesian capital market. We also control the changes of firms' size in the different period of observation. In addition, we finally include the entire sample into the consolidated data that is needed for further analysis in descriptive analysis, and panel data regression model in the hypotheses testing.

Grouping samples and dividing them into three categories are obviously necessary for controlling, neutralizing and cleaning the effects of exogenous variables on the endogenous variables. In line with the opinion of Baltagi (2008), controlling sample into several groups is needed to avoid the presence of bias when implementing the statistical analysis. In this study, we divide and classify the size of the companies by scaling their market capitalization. The proportion of each firm size is ranked from the smallest to the largest. Furthermore, to obtain the robust test results, we also consolidate the sample by combining the entire samples and conducting the test in panel data procedure. The information of summary statistics about three groups of samples (small, medium, large) and the consolidated data are available in Table 4.

Table 4 presents the summary statistics output, in which the information in Table 4 contains the descriptive statistics data set of four groups of samples. Panel A is the sample group for the company incorporated in the category of small-sized. The number of cross-sectional sample in this group is 25 companies. Panel B consists of the mediumsized company with the number of crosssectional sample as 33 companies, and Panel $\mathrm{C}$ is the large-sized companies with the cross-sectional sample of 25 companies. We also add further information in Panel $\mathrm{D}$, in which we set the consolidated sample from 83 companies with the total specific observation as 5,976 observations.

The result shown in Table 4 displays the relevant information which is done by classifying the sample into three parts. According to the data, it can be observed that most of the average level of information 
Table 4. Summary Statistics

Panel A: Small-Size Sample with 25 cross-sections (1,800 firm-month observations)

\begin{tabular}{lrrrr}
\hline Variable & Mean & Max & Min & Stdv \\
\hline RET & 0.07 & 0.39 & -1 & 1.16 \\
GT & 13.3 & 100 & 0 & 25.31 \\
P & 1334 & 51250 & 50 & 27.59 \\
TV & 43.95 & 123.77 & -26.15 & 25.96 \\
PER & 15.51 & 344.16 & -445.79 & 67.43 \\
AGE & 10.18 & 21 & 0 & 5.55 \\
DP & 13.24 & 944.99 & 0 & 80.65 \\
DY & 0.53 & 11.31 & 0 & 1.49 \\
DER & 2.22 & 38.79 & 0 & 3.89 \\
ROI & 1.36 & 18.62 & -30.35 & 7.02 \\
ROE & -0.53 & 70.34 & -206.26 & 34.54 \\
INFLATION & 6.06 & 12.14 & 2.41 & 2.47 \\
I_RATE & 7.21 & 9.5 & 5.75 & 1.17 \\
E_RATE & 9471.347 & 12212 & 8551 & 754.3 \\
GDP & 5.97 & 6.51 & 4.31 & 0.70 \\
\hline
\end{tabular}

Panel B: Medium-Size Sample with33 cross-sections (2,376 firm-month observations)

\begin{tabular}{lrrrr}
\hline Variable & Mean & Max & Min & Stdv \\
\hline RET & 0.04 & 0.11 & -0.92 & 0.50 \\
GT & 11.8 & 100 & 0 & 24.904 \\
P & 4200 & 156500 & 100 & 156.22 \\
TV & 68.41 & 142.884 & -15.905 & 27.307 \\
PER & 29.13 & 1193.89 & -34.62 & 105.19 \\
AGE & 14.47 & 31 & 1 & 5.63 \\
DP & 16.45 & 500.03 & 0 & 51.307 \\
DY & 1.83 & 27.69 & 0 & 4.35 \\
DER & 1.7 & 14.29 & 0 & 1.692 \\
ROI & 6.2 & 50.95 & -66.73 & 12.035 \\
ROE & 20.85 & 1703 & -200.71 & 124.2 \\
INFLATION & 6.06 & 12.14 & 2.41 & 2.47 \\
I_RATE & 7.21 & 9.5 & 5.75 & 1.17 \\
E_RATE & 9471.347 & 12212 & 8551 & 754.3 \\
GDP & 5.97 & 6.51 & 4.31 & 0.70 \\
\hline & & & &
\end{tabular}

Panel C: Large-Size Sample with 25 cross-sections (1,800 firm-month observations)

\begin{tabular}{lrrrr}
\hline Variable & Mean & Max & Min & Stdv \\
\hline RET & 0.05 & 0.39 & -1 & 0.80 \\
GT & 13.67 & 100 & 0 & 25.34 \\
P & 7809 & 740000 & 50 & 360.6 \\
TV & 66.19 & 196.636 & -26.150 & 31.73 \\
PER & 22.11 & 1193.89 & -445.79 & 77.02 \\
AGE & 13.57 & 31 & 0 & 6.06 \\
DP & 17.18 & 944.99 & 0 & 57.99 \\
DY & 1.75 & 31.33 & 0 & 4.34 \\
DER & 1.66 & 38.79 & 0 & 2.48 \\
ROI & 8.14 & 62.16 & -66.73 & 12.55 \\
ROE & 18.69 & 1703 & -206.26 & 83.98 \\
INFLATION & 6.06 & 2.41 & 2.47 & 6.06 \\
I_RATE & 7.21 & 5.75 & 1.17 & 7.21 \\
E_RATE & 9471.347 & 8551 & 754.3 & 9471.347 \\
GDP & 5.97 & 4.31 & 0.7 & 5.97 \\
\hline
\end{tabular}


Panel D: Consolidated Sample with 83 cross-sections (5,976 firm-month observations)

\begin{tabular}{lrrrr}
\hline Variable & Mean & Max & Min & Stdv \\
\hline RET & 0.05 & 0.39 & -1 & 0.80 \\
GT & 13.67 & 100 & 0 & 25.34 \\
P & 7809 & 740000 & 50 & 360.6 \\
TV & 66.19 & 196.636 & -26.150 & 31.73 \\
PER & 22.11 & 1193.89 & -445.79 & 77.02 \\
AGE & 13.57 & 31 & 0 & 6.06 \\
DP & 17.18 & 944.99 & 0 & 57.99 \\
DY & 1.75 & 31.33 & 0 & 4.34 \\
DER & 1.66 & 38.79 & 0 & 2.48 \\
ROI & 8.14 & 62.16 & -66.73 & 12.55 \\
ROE & 18.69 & 1703 & -206.26 & 83.98 \\
INFLATION & 6.06 & 2.41 & 2.47 & 6.06 \\
I_RATE & 7.21 & 5.75 & 1.17 & 7.21 \\
E_RATE & 9471.347 & 8551 & 754.3 & 9471.347 \\
GDP & 5.97 & 4.31 & 0.7 & 5.97 \\
\hline
\end{tabular}

retrieval (search engine query data) is dominated by large-sized companies (large). As seen in Table 4, the highest level of information searches conducted through Google stands around $15.85 \%$ on average in the large-sized companies (Panel C), followed by small-sized company (Panel A) as $13.3 \%$ on average and medium-sized company (Panel B) as $11.80 \%$ on average respectively. These findings indicate that although the awareness of prospective investors and market participants still focuses on the large-sized company, in fact, the small-size companies also considerably attract the attention of prospective investors and other market participants. This result was also accompanied by the obtained returns of each group of sample size. The small-sized companies (Panel A) show the positive average returns as $0.07 \%$ on average. Moreover, the medium-sized companies (Panel B) show lower returns as $0.04 \%$ and the large-sized companies (Panel B) generate average monthly returns as $0.06 \%$ on average. This output illustrates that small-sized companies are able to deliver returns above the average returns as generated by the large-sized companies. It is reasonable as to attract the attention of prospective investors, the small-sized companies have to be able to provide a higher rate of returns that can compensate the risk incurred by the investors when they invest their money in the small-sized companies.

Furthermore, we also conducted the descriptive analysis regarding the liquidity, which is surrogated by trading volume (TV). The information obtained from Table 4 shows that the highest average trading volume (TV) is noted in the group of largesized companies (Panel C), where its trading volume is reported as 86.03 on average. In the group of medium-sized company, the average trading volume is around 68.41 on average, and followed by 43.95 for the average trading volume of the small-sized company. The information regarding the trading volume is obtained by firstly calculating the natural logarithm (LN) of the trading volume itself. Hereby, we use the specific formula of Chordia et al., (2001); Chordia et al., (2007) in collecting the data related to trading volume. We do the multiplication between the information of trading volume of stock $\mathrm{i}$ in month $\mathrm{t}$ with the stock price (market value) of stock $i$ in month $t$. Thus, it can be inferred that 
information seekers (prospective investors and market participants) considering to make buying and selling decision based on the company size. Additionally, the information also illustrates that the large-sized companies are indicated to show a higher level of liquidity than other groups of samples. The consideration concerning the high liquidity of large companies can be identified through the factor of firm characteristics (AGE). Company's age gives a signal to the prospective investors that the large-sized companies are more likely able to provide more consistent returns with comparable level of risks for its investors. It can also be identified from the descriptive information, where the companies classified in the largesized sample group have already been in operation for approximately 15 years. Conversely, companies which are categorized in the small-sized group generally has been in operation for ten years on average, and followed by medium-sized companies which have been in operation for 14 years on average.

In line with the concept of "high risk, high return," investors prefer to collect the most relevant and reliable information to support their investment decisions. Some part of this information can be linked to the fundamental information as obtained from financial statements (microeconomic information). Hereby, we use fundamental information as the controlling variables such as price earnings ratio (PER), firms' age (AGE), dividend payout ratio (DP), the dividend yield (DY), debt-to-equity ratio (DER), return on investment (ROI), return on equity (ROE), and the stock price (LNP). Descriptive information as obtained from our sample illustrates three quite diverse groups of data. In general, each company which is classified into large-size companies is commonly performing better financial fundamentals rather than the other companies in the small-size and mediumsize group. This can be justified through several variables, such as the difference in dividend payout ratio (DP), the dividend yield (DY), debt-to-equity ratio (DER), return on investment (ROI), and return on equity (ROE).

\subsection{Testing the magnitude of Small, Medium, and Large-size sample in the first statistical model (Returns)}

In this study, we carefully test the first statistical model which is aimed to investigate the effect of each independent variable on the dependent variable (RET). In this step, the empirical testing is done by employing Google Trends (GT) as the main independent variable. The obtained output shows that information retrieval over the internet (Google) has especially brought negative and significant effect $(p<0.01)$ on the firm performance, which is proxied by returns (RET). The more comprehensive outputs on three groups of samples are available in Table 5.

In Table 5, we specifically run the empirical testing as performed on the smallsize, medium-size and large-size sample. Also, we hereby meticulously calculate the coefficient of variable GT which reflects the negative and significant result at the level of $1 \%$ and $5 \%$ in the three subsample groups. This indicates that during the period of observation from January 2007 to December 2012, the amount of incoming information into the market more likely caused investors to react negatively. In addition to this, microeconomic information relating to the company's fundamental information such as price earnings ratio (PER), the dividend 
payout ratio (DP), dividend yield (DY), debtto-equity ratio (DER), return on investment (ROI), and return on equity (ROE) shows various results. Surprisingly, refers to the statistical output, the influence of microeconomic factors on stock returns are all statistically significant in the group of medium-sized companies. Moreover, our result is quite surprising, particularly in the statistical output of small-sized companies. In regard to the testing of panel data on 25 companies with the number of data as of 1,800 firm-month observations, the chow and hausman test recommend to use random effect model (REM). This output, in fact, is quite consistent with the conditions and events occurred during the period of observation. In 2008, the Indonesian capital market was temporarily suspended for a certain time limit to anticipate the impact of the global financial crisis and internet bubble. Fortunately, due to this policy enaction, the Indonesian composite index did not further experience severe negative trend pertaining to the global financial crisis shock. Even though there was a negative decrease on the market value of Indonesian composite index in December 2008, positive trend was regained in 2009.

Further investigation on the contribution of macroeconomic variables such as inflation, interest rates, exchange rate, and economic growth (GDP) shows the consistent result with the study of Czaja et al., (2010). In the small-size and mediumsize sample group, the impact of inflation shows negative and significant $(p<0.01)$ effect on stock returns. This means that the

Table 5. Panel data regression output with Return (RET) as the dependent variables

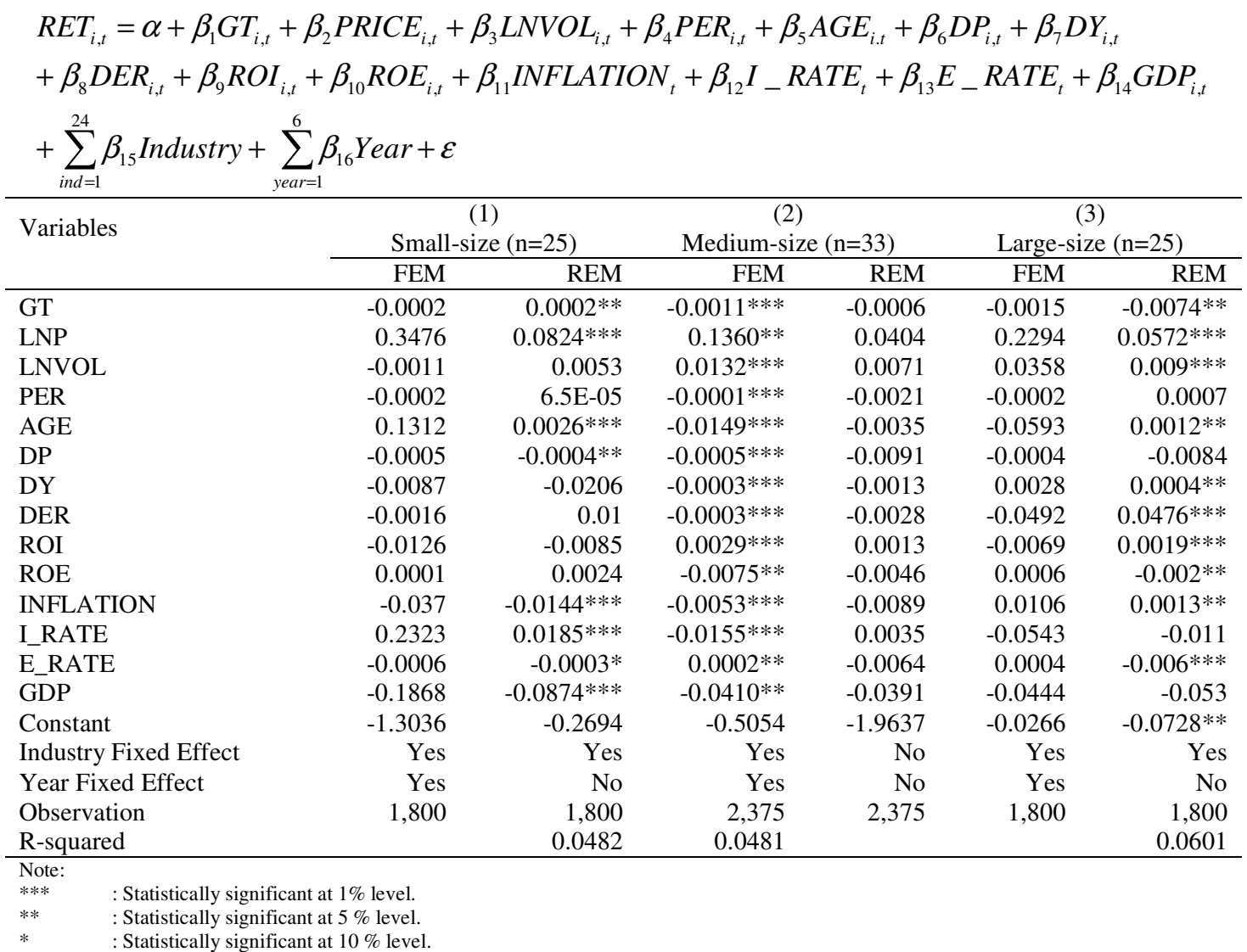


higher inflation tends to result in a decrease of company's ability in generating positive returns. In contrast, the impact of inflation is positive and significant $(p<0.05)$ at the largesized companies. This indirectly implies that large-sized companies tend to be more stable in anticipating the negative effect of inflation than the small-sized and medium-sized companies. Moreover, the effect of interest rate shows negative association with company performance which is measured by returns. In line with previous findings on the macroeconomic factors, changes in the Indonesian Rupiah (IDR) against the US dollar also negatively influence the value of stock returns. The weaker the intrinsic value of Indonesian IDR against the US dollar results in the smaller returns. This condition arises due to the production with raw material prices that have to be paid in the US dollars gets higher. In this circumstance, the companies in the manufacturing industry are forced to raise the product prices which more likely led to a reduction in demand for products or services.

Other macroeconomic factors such as economic growth (GDP), is surprisingly shows the negative association with the firms' returns. The results show consistent output in each group of sample. Although the overall Indonesian economy is still in positive circumstance, GDP displays negative impact on returns. This condition is considerably triggered by the condition of the internet bubble and global financial crisis, where in 2008 most of global capital markets were suffering from this problem. However, Indonesian economy in general was not severely impacted, since Indonesian real sector was considerably quite strong to anticipate the negative impact of the global crisis and internet bubble.
4.4. Testing the magnitude of Small, Medium, and Large-size sample in the second statistical model (Trading Volume)

We also perform the same procedure in testing the second statistical model. In this section, we identify the effect of each independent variable on the dependent variable (trading volume). Similar to the testing in the first statistical model, the partition of sample into three groups is aimed at conducting investigation in the different levels of information retrieval (search engine query data). The statistical output of panel data analysis is available in Table 6.

Statistical output in Table 6 is obtained by employing panel data analysis with trading volume (TV) as the proxy of liquidity. As seen in Table 6, it is noted that variable GT is positively associated with TV. In this context, we conjecture that either the increased returns as realized by the investors, or investors' recognition on the negative outlook of stock performance trigger them to search a particular stock which is able to show promising benefit. This eventually results in the increase of stock demands or the increase of stock offers which lead to more transactions in market. The higher the demand for a certain stock which is followed by the supporting public information, associate with more fluctuative and relatively easier stock to be traded. Thus, we do suggest that the search of information via the internet positively contributes to the trading volume. Besides, macroeconomic factors considerably show negative effects on the liquidity, while the fundamental information as represented by microeconomics variables reflect positive effects on liquidity as surrogated by trading volume. 
Table 6. Panel data regression output with Trading Volume (TV) as the dependent variable

\begin{tabular}{|c|c|c|c|c|c|c|}
\hline \multirow[t]{2}{*}{ Variables } & \multicolumn{2}{|c|}{$\begin{array}{c}(1) \\
\text { Small-size }(\mathrm{n}=25)\end{array}$} & \multicolumn{2}{|c|}{$\begin{array}{c}(2) \\
\text { Medium-size (n=33) }\end{array}$} & \multicolumn{2}{|c|}{$\begin{array}{c}(3) \\
\text { Large-size (n=25) }\end{array}$} \\
\hline & FEM & REM & FEM & REM & FEM & REM \\
\hline GT & 0.0362 & $0.0444 * * *$ & -0.0010 & $0.0021 * * *$ & $0.0162 * *$ & 0.0162 \\
\hline LNP & 13.9199 & $13.2453 * * *$ & 14.4467 & $14.2349 * * *$ & $6.8516^{* * *}$ & 6.7447 \\
\hline PER & -0.0014 & -0.001 & -0.0025 & -0.0025 & 0.0154 & 0.0173 \\
\hline AGE & 1.5533 & $0.5146 * * *$ & -0.4502 & $-0.8669 * *$ & $-1.0373 * *$ & -0.826 \\
\hline DP & -0.0079 & $-0.0085 *$ & -0.0174 & -0.0173 & 0.0083 & 0.007 \\
\hline DY & 0.4587 & $0.4098^{* *}$ & 0.2993 & 0.2983 & -0.1051 & -0.106 \\
\hline DER & -0.6886 & $-0.7604 * * *$ & 0.7618 & 0.7901 & -1.3308 & -1.323 \\
\hline ROI & 0.6584 & $0.6849 * *$ & 0.0104 & $0.0064 * * *$ & $0.3687 * * *$ & -0.366 \\
\hline ROE & -0.0779 & $-0.0855^{* *}$ & -0.0006 & -0.0006 & $0.2975^{* * *} *$ & 0.2928 \\
\hline INFLATION & -0.7119 & $-0.532 * * *$ & 0.0518 & $0.1205^{* *}$ & -0.0840 & -0.116 \\
\hline I_RATE & -0.1493 & $-1.7693 * * *$ & 1.5512 & $0.8802 * *$ & $2.6909 * * *$ & -2.389 \\
\hline E_RATE & -0.0017 & $-0.0013 * * *$ & -0.0023 & $-0.0021^{*}$ & 0.0006 & 0.0005 \\
\hline GDP & 1.0022 & $1.5591 * * *$ & -2.3833 & $-2.1349 * *$ & $3.0196^{* * *}$ & 2.8812 \\
\hline Constant & 69.2185 & $72.6639 * * *$ & 73.4344 & $79.7804 * * *$ & $58.0287 * *$ & 51.6296 \\
\hline Industry Fixed Effect & Yes & Yes & Yes & Yes & Yes & No \\
\hline Year Fixed Effect & Yes & No & Yes & No & Yes & No \\
\hline Observation & 1,800 & 1,800 & 2,375 & 2,375 & 1,800 & 1,800 \\
\hline R-squared & \multicolumn{6}{|c|}{$\begin{array}{l}\text { R-squared } \\
\text { Note: }\end{array}$} \\
\hline $\begin{array}{ll}\text { Note: } & \\
* * * & : S t \\
* * & : S t\end{array}$ & $\begin{array}{l}\text { level. } \\
\text { lever. }\end{array}$ & & & & & \\
\hline & $\%$ level. & & & & & \\
\hline
\end{tabular}

The output of Panel data tests in three groups of samples show consistent results. The result as shown in Table 6 displays that the higher search of information on the internet contributes positively to the liquidity. This is in line with the test on a small-sized sample group and is noted significant at $1 \%$ level. Moreover, the tests on the medium-sized and large-sized companies are also reported significant at the level of $1 \%$ and $5 \%$ respectively. Positive effect as displayed by the statistical output in the second model (trading volume) is certainly different from the output of the first model (returns). Testing in model one shows that the contributions of GT to returns is negative, while in model two the contribution of GT to trading volume is positive. This indicates that although the value of returns is negative after being retrieved by the investors on the internet, the levels of trading volume in three groups of samples are still high. This is motivated by the increasing amount of information available in the market, so that the obtained information through the internet tends to drive the market to react negatively. In this circumstance, there are many investors who intend to hold their stocks for the long-term period, and even anticipate the liquidity risk which reduces the firm performance. Moreover, they also tend to sell their shares at a certain price level that is relatively inexpensive, where this situation is commonly triggered by the short-term stock traders. 


\subsection{Hypothesis Testing}

Hypothesis testing is conducted by employing panel data regression on both the statistical research models $(1 \& 2)$. At this stage, we use 14 independent variables (variable of interests and control variables) to test the causality between the independent and dependent variables (RET \& TV). However, in this case, we concentrate on the causal relation that occurs between the main variables, namely Google Trends (GT), stock returns (RET) and Trading Volume (TV). Meanwhile, the use of other independent variables such as LNVOL, PER, DP, DY, DER, ROI and ROE is intended as control variables. The panel data regression output is available in Table 7.

In the first hypothesis testing, we firstly focus on elaborating the statistical

Table 7. Panel data regression outputs on RET and TV

\begin{tabular}{|c|c|c|c|c|c|c|}
\hline \multicolumn{7}{|c|}{ 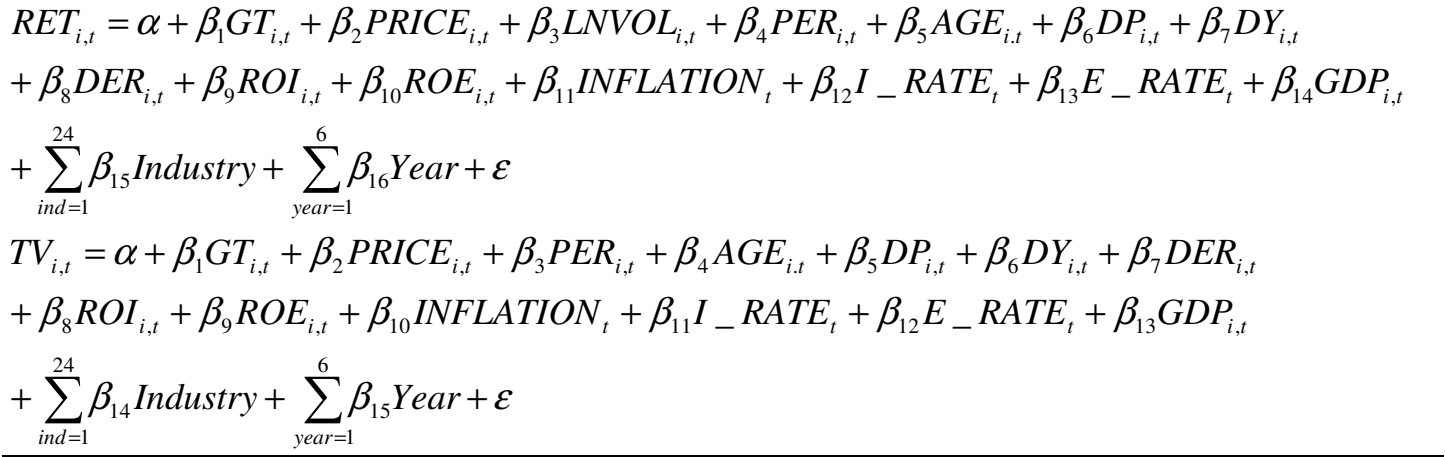 } \\
\hline \multirow{3}{*}{ Variables } & \multicolumn{3}{|c|}{$\begin{array}{c}\text { (Model 1) } \\
\text { RET }\end{array}$} & \multicolumn{3}{|c|}{$\begin{array}{c}\text { (Model 2) } \\
\text { TV } \\
\end{array}$} \\
\hline & \multirow{2}{*}{$\begin{array}{l}\text { Predicted } \\
\text { Sign }\end{array}$} & \multicolumn{2}{|c|}{ Model } & \multirow{2}{*}{$\begin{array}{l}\text { Predicted } \\
\text { Sign }\end{array}$} & \multicolumn{2}{|c|}{ Model } \\
\hline & & Fixed & Random & & Pooled & Fixed \\
\hline GT & $+/-$ & $-0.0009 * *$ & -0.0004 & + & $0.0464 * * *$ & 0.0151 \\
\hline LNVOL & + & $0.1939 * * *$ & 0.0409 & & & \\
\hline LNP & + & $0.0144 * * *$ & 0.0020 & + & $7.3490^{* * *}$ & 11.8489 \\
\hline PER & + & -0.0008 & -0.0017 & + & $0.0110^{* *}$ & -0.0006 \\
\hline AGE & + & 0.0167 & -0.0032 & + & $-0.4263 * * *$ & -0.2166 \\
\hline DP & + & -0.0009 & -0.0001 & + & $-0.0419 * * *$ & -0.0012 \\
\hline DY & + & $0.0009 * *$ & -0.0037 & + & $0.5811 * * *$ & 0.0042 \\
\hline DER & - & -0.0008 & 0.0023 & - & $-1.1978 * * *$ & -0.2273 \\
\hline ROI & + & -0.0006 & -0.0010 & + & $0.0805^{* *}$ & 0.0439 \\
\hline ROE & + & $-0.0001 * *$ & -0.0009 & + & $0.0135^{* * *}$ & 0.0077 \\
\hline INFLATION & - & -0.0109 & -0.0078 & - & -0.1215 & -0.1253 \\
\hline I_RATE & - & $0.0511 * *$ & -0.0006 & - & $-1.1155^{* *}$ & -0.5461 \\
\hline E_RATE & - & $0.0003 * *$ & -0.0016 & - & $-0.0018 * *$ & -0.0010 \\
\hline GDP & + & $-0.0849 * * *$ & -0.0521 & + & 0.4358 & -0.0231 \\
\hline Constant & & $-0.0065^{* *}$ & -0.0079 & & $42.5686 * * *$ & 1.1751 \\
\hline Industry Fixed Effect & & Yes & No & & Yes & Yes \\
\hline Year Fixed Effect & & Yes & No & & Yes & Yes \\
\hline Observation & & 5,976 & 5,976 & & 5,976 & 5,976 \\
\hline R-squared & & 0.0398 & & & 0.2158 & \\
\hline
\end{tabular}

Note:

N**: : Statistically significant at $1 \%$ level.

** : Statistically significant at $5 \%$ level.

* : : Statistically significant at $10 \%$ level. 
information in column 1 (model 1 ). We conjecture that there is an association of the increasing information search done by either the current investors or potential investors on stock returns. As seen in Table 7, the coefficient of variable GT shows a significant effect on returns. Therefore, the proposed hypothesis is statistically supported, even though the value of the coefficient itself is very low (-0.0009). Hereby, we note that the coefficient value and the sign of the variable GT shows a negative and significant effect $(p<0.05)$ on returns. Thus, we draw the conclusion that the first hypothesis is supported.

As previously explained, the information of the microeconomic variables could also be retrieved through the annual report or financial statements. This information is commonly opened and accessible on the internet. By utilizing search engine platform like Google, financial information can be accessed. Moreover, the use of control variables such as PER, DP, DY, DER, ROI, and ROE is intended to take the role as the public information (these major ratios are publicly available on the page of Google finance, Yahoo finance, Bloomberg, Thompson Reuters and so forth). The logarithm natural of the stock price (LNP), the logarithm natural of the shares traded (LNVOL), firm age (AGE), and dividend yield (DY) show positive effects on returns. However, on the other hand, some microeconomic information such as price earnings ratio (PER), dividend payout (DP), debt-to-equity ratio (DER), return on investment (ROI) and return on equity (ROE) contribute negatively to returns. In this regard, management disclosure of the financial information is somehow varying in their degree of precision. Mercer, (2004) argues that some of information such as management's earning forecast emerges as (i) precise point estimates, (ii) less precise range estimates, and (iii) vaguer one-sided maximum or minimum estimates. Due to this vary precision, the imprecise disclose of certain information signals management's uncertaintly. This eventually viewed as less credible information than more credible information disclosure (Hassell et al., 1988).

Furthermore, the effect of inflation on the stock returns of public listed companies show consistent result with the a priori theory, in which an increase in the inflation negatively correlated with returns (Peavy \& Goodman, 1985). Although the causal test as shown by the variable inflation to returns is negative, but this result was statistically insignificant. Further, the control variable shows positive sign and statistically significant $(p<0.01)$. This result indicates that the higher interest rate positively results in an increase in returns. However, this is inconsistent with the a priori theory, where the expected sign of interest rate is negative. The next macroeconomic variable focuses on the effect of exchange rate on returns. The obtained results by applying fixed effect model approach shows that the exchange rate performs positive and significant $(p<0.05)$ effect on returns. Moreover, economic growth as measured by GDP contributes positively to the stock returns.

After conducting statistical interpretation by using the recommended model (fixed effect model) in the statistical model one, in testing the statistical model two, we further examine the impact of investors' attention (GT), macroeconomic factors, and microeconomic factors on stock liquidity. Hereby, before implementing the panel data analysis, procedural testing is necessarily important to compare three of the available models in panel data analysis (pooled least 
squares (PLS), fixed effect model (FEM), or random effects model (REM)). The statistical outputs using chow test recommends to adopt PLS model as the most efficient and appropriate method of testing the statistical model two.

In line with the results by employing the PLS model in Table 7, the coefficient of investors' attention as represented by Google Trend (GT) shows positive effect on liquidity (see Table 6). This result indicates consistency even when the test is performed by controlling the company size into three groups of samples. The test using consolidated sample reflects that the more incoming information entering the market, it presumably takes role to facilitate the potential investors in finding out several relevant information of the prospective stocks. Thus, the hypothesis two which conjectures investor's attention positively affects the trading volume (TV) statistically and significantly supported $(p<0.01)$.

Further test is conducted to investigate the contribution of macroeconomic factors on stock liquidity. The first macroeconomic factor used in the statistical model two tests the effect of inflation on stock liquidity. The output indicates that inflation has negatively affected the trading volume (TV). It denotes that the higher inflation tends to show an impact on the inability of investors to buy certain shares in a large lot size. Also, the common thread between the expectations of positive returns and high liquidity stocks cannot be achieved if the inflation is out of control (Peavy \& Goodman, 1985). The next test of controlling variable is done by employing interest rate on trading volume. We assume that there is negative relationship between interest rate and stock liquidity. The assumption is in line with the results as shown in panel data analysis output in Table
7 , where the coefficient of interest rate shows negative sign and statistically significant ( $p<$ 0.05 ). The variable exchange rate is also examined as the controlling variable. The result shows that the contribution of the exchange rate to trading volume is negative and significant $(p<0.05)$. The test on the last macroeconomic variable is proofing the effect of economic growth (GDP) on stock liquidity. The output reveals that GDP has shown a positive effect. The higher economic growth as measured by Gross Domestic Product (GDP) during the period from 2007 to 2012 contributes positively to the stock liquidity. In this case, the decision to insert macroeconomic data is taken since we consider the endogeneity problem due to the omitted variable bias.

As previously noted by Baltagi (2008), test using controlling variable such as microeconomic factors are considerably important to neutralize the effect derived from the main variables. With these motives, we use control variables comprising a wide range of fundamental financial information and macroeconomic variables that can be easily obtained on the internet (Google). Hereby, the effect of the natural logarithm of stock price (LNP) on liquidity (TV) indicates positive and significant $(p<0.01)$ effect. Price earnings ratio (PER) also shows the similar result, where it displays positive and significant $(p<0.01)$ effect on liquidity (TV). Firms' age (AGE) indicates that the older the companies' age, the lower its trading volume would be due to the more stable and the consistency of stock price changes. This is quite reasonable since the company follows a life cycle pattern in its business operation. The stock of young firms is commonly more volatile and actively traded than old firms. In addition, the young firm that just launched its initial public offering (IPO) somehow seems 
to be more attractive than the wellestablished firm which has been in operation for many decades. It is considered that the attractiveness of young firms after being registered in IPO emerges, as the stock traders show an opportunistic behavior to seek short-term profit from the volatily of young firms' stock prices.

Moreover, the coefficient of variable dividend payout ratio (DP) shows a negative sign of its relationship with stock liquidity (TV). Otherwise, the dividend yield (DY) shows a positive sign. Debt-to-equity ratio (DER) performs negative and significant $(\mathrm{p}<$ $0.01)$ contribution to liquidity (TV). The higher debt-to-equity ratio would have the negative impact on liquidity. It is reasonable since the high DER ratio indicates high-risk profile. Therefore, stocks with high debt ratios tend to be more illiquid. Other financial information such as return on investment (ROI) and return on equity (ROE) are utilized to see whether they can explain the variation in trading volume (TV). The results in Table 7 reflects that the fundamental information such as ROI and ROE contribute positively and significantly $(p<0.01 \& p<0.05)$ to the variation of liquidity (TV). The higher profitability ratio eventually gives signals to the prospective investors that the firms are able to generate higher ex-ante returns and are easily traded at any time.

\subsection{Discussion}

The results of our study as shown by the statistical test on two models reveal several findings. First, we conjecture that there is an association and causal relationship between investors' attention as measured by information retrieval over the Internet (GT) on the firm performance which is measured by stock returns (RET). The results by using 83 most searched companies through the internet in the Indonesian stock exchange during the period 2007 to 2012 showed that the effect of investor's attention is negative and significant $(p<0.01)$. This result confirms the previous test in three different groups of samples which were controlled by the scale of market capitalization (SIZE). It is reported that even though the panel data test is conducted in the small, medium, and large-sized sample, the coefficient of GT on RET remains consistently. Therefore, we report that the hypothesis one is statistically supported.

Our findings indicate that the amount of incoming information as obtained by investors or potential investors on the internet is considered as public information. This public information is needed by the market participants, in which market is commonly reacting either positively or negatively based on the available information that is utilized by the investors to make the investment decision. Also, macro and microeconomic information that is open access on the annual report or internet can lead the stock returns to deviate positively or negatively, since it reflects the current market condition. The implication is that investors who have more information (informed investors) tend to hold their stocks or sell it based on the information they captured (Nurazi et al., 2016). Thus, the different information and the efforts of the firm disclosure are necessarily important to attract more investors, especially in shifting the investors from the un-informed investors to better-informed investors (Copeland, 1976). In the different point of view, Mercer, (2004) explains that investors are somehow putting the attention on the information disclosure credibility as posted on the 
internet. The investors perception of the believability of a particular disclosure is considerably essential to be highlighted. Once investors, potential investors, and the other market participants recognize the incoming information either through the disclosure from management or stock prices changes, they will capture the information and react based on the relevant information. Therefore, it is important for the uninformed investors to offset the incoming or the disclosed information not only based on the quantity of information itself, but also based on the quality of information.

Second, our results are consistent with the a priori theory which states that the high level of information retrieval helps investors to truncate the level of asymmetry information among them. We report that the use of internet (search engine query data) in obtaining the incoming information is able to explain the variation in liquidity, which is surrogated by trading volume (TV). It is very reasonable even though the investors' attention tends to negatively affect the returns. However, on the other situation, investors' attention positively affects the stock liquidity. Our investigation confirms that the incoming information could be useful in predicting the plausible firm performance in the future. Although the circumstance of Indonesian stock exchanges is sometimes little bit volatile due to the major economic shocks of the global financial trend, investors are still able to anticipate this situation and get out of the panic and overreaction condition by taking off some of their portfolio instruments at lower prices. Given the importance of external contribution of macroeconomic data, firms' decision when disclosing the information on the internet are also relate to some indicators. Mercer, (2004) further points out that the disclosure and information credibility are influenced by (i) the situational incentives at the same time of disclosure is conducted by the firms, (ii) management credibility, (iii) the degree of external and internal assurance on the disclosed information, (iv) the variation of characteristrics of the disclose, including the information precision, venue, timing, amount of supporting information and the inherent plausibility.

In this study, it is notably argued that asymmetry information exists among investors. In fact, there is a group of investors who have better information and vice versa. Both types of these investors are introduced by Copeland, (1976) as informed investors (investors who are exposed and better informed) and un-informed investors (investors who are not informed). To overcome the gap related to such type of information, internet is considerably important as the alternative solution of information provider. Several studies have revealed that the activity of searching information on the Internet can facilitate potential investors with the public information in reducing the information asymmetry (see. Bank et al., 2011; Da et al., 2011; Drake et al., 2012; Usman \& Tandelilin, 2014; Nurazi et al., 2015a; Nurazi \& Usman, 2015). Kinney, (2000) also provides corroborating empirical evidence where the voluminous anecdotal evidence indicates that the opinion of the third independent parties (e.g. financial analyst, auditors and stock brokers) regarding the incoming information might affect the investors', prospective investors' and the market participants' perception on the information itself. This is what underlies our findings, in which the amount of incoming information into the market is not only 
composed of specific information about the macroeconomic information, but also information derived from the internal firms (microeconomic information) as the public information.

Our study also confirms that most of the macroeconomic factors have shown negative implications on the firm performance, either on the firm returns or liquidity. The increase of inflation, interest rate, and the weakening of exchange rate negatively affect the stock returns and stock liquidity. In contrast, the higher economic growth (GDP) positively affects the liquidity, but in our case, it negatively affects the stock returns during the observed period. This considerably could be happened due to the calibration of Indonesian economic condition that is quite vulnerable to the symptoms of economic shock (e.g. global financial crisis due to the internet bubble in 2008). This condition was more likely acting as the triggering factor of temporary suspension in Indonesian capital market, where in this regards, Choi and Varian, (2012) mention that generally, macroeconomics data inclined to be represented as a random walk.

\section{CONCLUSION REMARKS}

Based on the investigation on 83 mostsearched companies in the Indonesian stock exchange, it can be inferred some conclusions. We argue that information asymmetry exists in the Indonesian capital market. By employing the combination of available macroeconomic and microeconomic information through the internet search activity, we report that internet search as the reflection of investors' attention considerably contributed to the variations of returns and liquidity of public listed company in the Indonesia Stock Exchange. We also note that investors' attention as surrogated by searching activity on the Internet (Google) negatively and significantly $(p<0.01)$ contributes to the variation of stock returns (RET). Further, investors' attention positively contributes to liquidity as proxied by trading volume (TV). Other controlling variables such as inflation, interest rate, exchange rate, and economic growth (GDP) are reported to show significant effects along with the microeconomics variables.

\section{References}

Aerts, W., Cormier, D., \& Magnan, M. (2008). Corporate environmental disclosure, financial markets and the media: An international perspective. Ecological Economics, 64

(3), 643-659.

Ashbaugh, H., Johnstone, K. M., \& Warfield, T. D. (1999). Corporate reporting on the internet. Accounting Horizons, 13 (3), 241-257.

Axjonow, A., Ernstberger, J., \& Pott, C. (2018). The impact of corporate social responsibility disclosure on corporate reputation: a non-professional stakeholder perspective. Journal of Business Ethics, 151 (2), 429-450.

Baltagi, B.H. (2008) Econometric Analysis of Panel Data. John Wiley \& Sons Ltd., Chichester

Bank, M., Larch, M., \& Peter, G. (2011). Google search volume and its influence on liquidity and returns of German stocks. Financial Markets and Portfolio Management, 25 (3), 239-264.

Beretta, S., \& Bozzolan, S. (2008). Quality versus quantity: the case of forward- 


\title{
ДА ЛИ ПОДАЦИ ЗА УПИТЕ ПРЕТРАЖИВАЧА ДОПРИНОСЕ ЗАРАДИ И ЛИКВИДНОСТИ?
}

\author{
Ridwan Nurazi, Berto Usman
}

\section{Извод}

Ова студија покушава да идентификује утицај пажње инвеститора који је замењен подацима за упите претраживача података на интернету помоћу “Google-a" на зараде и ликвидност. Подаци коришћени у овој студији су издвојени из "Google Trend" сета података и комбиновани са ручно прикупљеним подацима из Индекса тржишта капитала Индонезије (“ICMD”). Користећи панел анализу података, наши резултати показују да су подаци упита за претраживаче (проналажење информација) помоћу интернета (“Google”) очигледно важан метод ублажавања нивоа асиметричности информација између информисаних и неинформисаних инвеститора. Штавише, коришћење микроекономских фактора, као што су финансијске или нефинансијске информације које се лако могу добити из годишњих извештаја, веома су корисне у помагању инвеститорима у припреми њиховог портфолија инвестиција. У међувремену, макроекономски фактори као што су инфлација, каматна стопа, девизни курс и БДП су ефекти на нивоу земље што резултира или позитивним или негативним утицајем на зараде и ликвидност. Користећи 83 узорка и шестогодишњи период посматрања, може се закључуити да су добијене информације кроз податке о упитима претраживача података на интернету, макроекономски фактори и микроекономски фактори снажно и значајно везани за зараде и ликвидност на индонезијској берзи.

Кључне речи: интернет, “Google”, микроекономија, информације о макроекономији

looking disclosure. Journal of Accounting, Auditing \& Finance, 23 (3), 333-376.

Brigham, E.F., \& Houston, J.F. (2007). Fundamentals of financial management (Eleventh Ed.) Thomson Higher Education. 5191 Natorp Boulevard, Mason, OH, USA

Chan, H., Faff, R., \& Ramsay, A. (2005). Firm size and the information content of annual earnings announcements: Australian evidence. Journal of Business Finance and Accounting, 32 (1-2), 211-253.

Chen, S. (2011). Google search volume : influence and indication for the Dutch stock market (Bachelor Thesis). Erasmus University Rotterdam. Retrieved from http://citeseerx.ist.psu.edu/viewdoc/downloa d?doi=10.1.1.920.1354\&rep=rep1\&type $=$ pd $\mathrm{f}$
Choi, H., \& Varian, H. (2012). Predicting the present with Google Trends. Economic Record, 88 (s1), 2-9.

Chordia, T., Huh, S.W., \& Subrahmanyam, A. (2007). The crosssection of expected trading activity. The Review of Financial Studies, 23 (9), 709-740.

Chordia, T., Roll, R., \& Subrahmanyam, A. (2001). Market liquidity and trading activity. The Journal of Finance, 56 (2), 501-530.

Copeland, T.E. (1976). A model of assset trading under the assumption of sequential information arrival. The Journal of Finance, 31 (4), 1149-1168.

Czaja, M.G., Scholz, H., \& Wilkens, M. (2010). Interest rate risk rewards in stock 
returns of financial corporations: evidence 305-360.

from Germany. European Financial Joseph, K., Babajide Wintoki, M., \& Management, 16 (1), 124-154.

Da, Z., Engelberg, J., \& Gao, P. (2011). In Search of Attention. Journal of Finance, 66 (5), 1461-1499.

Deloitte Access Economics. (2011). The connected archipelago: The role of the Internet in Indonesia's economic development. Sydney NSW. Retrieved from www.deloitte.com.au

Dergiades, T., Milas, C., \& Panagiotidis, T. (2015). Tweets, Google trends, and sovereign spreads in the GIIPS. Oxford Economic Papers, 67 (2), 406-432.

Drake, M.S., Roulstone, D.T., \& Thornock, J.R. (2012). Investor information demand: evidence from Google searches around earnings announcements. Journal of Accounting Research, 50 (4), 1001-1040.

Fama, E., \& French, K. (1995). Size and book-to-market factors in earnings and returns. The Journal of Finance, 50 (1), 131-155.

Fogler, R., John, K., \& Tipton, J. (1981). Three Factors, Interest Rate Differentials and Stock Groups. The Journal of Finance, 36 (2), 323-335.

Gujarati, D.N., \& Porter, D.C. (2010). Econometria. McGraw-Hill. New-York.

Gündüz, L., \& Hatemi, A. (2005). Stock price and volume relation in emerging markets. Emerging Markets Finance \& Trade, 41 (1), 29-44.

Hassell, J.M., Jennings, R.H., \& Lasser, D.J. (1988). Management earnings forecasts: their usefulness as a source of firm specific information to security analysts. Journal of Financial Research, 11 (4), 303-319.

Jensen, M.C., \& Meckling, W.H. (1976). Theory of the firm: Managerial behavior, agency costs and ownership structure. Journal of Financial Economics, 3 (4), Zhang, Z. (2011). Forecasting abnormal stock returns and trading volume using investor sentiment: evidence from online search. International Journal of Forecasting, 27 (4), 1116-1127.

Kanas, A. (2008). A multivariate regime switching approach to the relation between the stock market, the interest rate and output. International Journal of Theoretical and Applied Finance, 11 (7), 657-671.

Kinney, W.R. (2000). Information quality assurance and internal control For management decision making.

Irwin/McGraw-Hill. Burr Ridge. IL

Mercer, M. (2004). How do investors assess the credibility of management disclosures? Accounting Horizons, 18 (3), 185-196.

Michelon, G., Pilonato, S., \& Ricceri, F. (2015). CSR reporting practices and the quality of disclosure: An empirical analysis. Critical Perspectives on Accounting, 33, 59-78.

Nurazi, R., Kananlua, P. S., \& Usman, B. (2015a). The effect of google trend as determinant of return and liquidity in Indonesia Stock Exchange. Journal Pengurusan, 45 (3), 131-142.

Nurazi, R., Santi, F., \& Usman, B. (2015b). Tunnelling: evidence from Indonesia stock exchange. Asian Academy of Management Journal of Accounting and Finance, 11 (2), 127-150.

Nurazi, R., \& Usman, B. (2015). Public attention and financial information as determinant of firms performance in the telecommunication sector. Jurnal Keuangan Dan Perbankan, 19 (2), 235-251.

Nurazi, R., Usman, B., \& Kananlua, P. S. (2016). Does bid-ask spread react to the increase of internet search traffic. 
International Research Journal of Business Studies, 8 (3), 181-196.

Peavy, J.W., \& Goodman, D.A. (1985). How inflation, risk and corporate profitability affect common stock returns. Financial Analysts Journal, 41(5), 59-65.

Ross, S. (1976). The arbitrage theory of capital asset pricing. Journal of Economic Theory, 13 (3), 341-360.

Su, Y.C., Huang, H.C., \& Lin, S.F. (2012). Dynamic relations between order imbalance, volatility and return of jump losers. Applied Economics, 44 (12), 1509-1519.

Sweeney, R., \& Warga, A. (1986). The pricing of interest-rate risk: evidence from the stock market. The Journal of Finance, 42 (2), 393-410.

Takeda, F., \& Wakao, T. (2014). Google search intensity and its relationship with returns and trading volume of Japanese stocks. Pacific Basin Finance Journal, 27 (1), 1-18.

Treynor, J.L. (1961). Market Value, Time, and Risk. Available at SSRN: https://ssrn.com/abstract $=2600356$
Turan, S.S. (2017). Internet search volume and stock return volatility: the Case of Turkish companies. Information Management and Business Review, 6 (6), 317-328.

Usman, B., \& Tandelilin, E. (2014). Internet search traffic and its influence on liquidity and returns of Indonesian stocks: an empirical study. Journal of Indonesian Economy and Business, 29 (3), 203-221.

Verma, P., \& Jackson, D. O. (2008). Interest rate and bank stock returns asymmetry: Evidence from U.S. banks. Journal of Economics and Finance, 32 (2), 105-118.

Verrecchia, R.E. (1990). Information quality and discretionary disclosure. Journal of Accounting and Economics, 12 (4), 365-380.

Zhang, W., Shen, D., Zhang, Y., \& Xiong, X. (2013). Open source information, investor attention, and asset pricing. Economic Modelling, 33, 613-619. 